\title{
TRANSKRYPCJA CZY TRANSLITERACJA NAZWISK UKRAIŃSKICH W POLSZCZYŹNIE? Z DZIEJÓW ORTOGRAFII
}

\author{
HELENA SOJKA-MASZTALERZ \\ Uniwersytet Wrocławski, Wrocław — Polska \\ ТРАНСКРИПЦІЯ ЧИ ТРАНСЛІТЕРАЦІЯ УКРАЇНСЬКИХ ПРІЗВИЩ \\ У ПОЛЬСЬКІЙ МОВІ? 3 ІСТОРІЇ ПРАВОПИСУ \\ ГЕЛЕНА СОЙКА-МАШТАЛЕЖ \\ Вроцлавський університет, Вроцлав - Польща
}

АНОТАЦІЯ. Стаття присвячена дослідженню транскрипції та транслітерації українських прізвищ у польській мові на матеріалі преси за 1991 та 2012 рр. у порівняльному аспекті. Проведений аналіз виявив, що існує потреба повторного опрацювання прозорих та розбірливих норм транскрибування українських антропонімів.

\section{TRANSCRIPTION OR TRANSLITERATION OF UKRAINIAN SURNAMES IN POLISH? THE HISTORY OF THE ORTHOGRAPHY}

\author{
HELENA SOJKA-MASZTALERZ \\ University of Wrocław, Wrocław — Poland
}

ABSTRACT. The article is dedicated to the investigation of the transcription and the transliteration of Ukrainian names in Polish on the material of the press releases published in 1991 and 2012. The analysis has shown that there is a necessity to redescribe perspicuous and readable rules of transcription and transliteration of Ukrainian antroponims.

W swojej książce Losy polskiej ortografii S. Jodłowski, powołując się na badaczy dziejów ortografii m.in. W. Taszyckiego i S. Rosponda, twierdził, że „nasza ortografia stanowiła w XVI w. w pełni dojrzały system”", ale dalej podawał - przytaczając za S. Urbańczykiem, że polską ortografię „czekały jeszcze późniejsze zmiany, wynikające $z$ chęci dostosowania pisowni do zmian zachodzących w żywej mowie"'. Jakie zatem były te zmiany i czego one dotyczyły, kto zajmował się w przeszłości, a kto dziś decyduje o zmianach zasad ortograficznych, także tych dotyczących pisowni obcych nazw własnych?

Zanim zatem zajmę się odpowiedzią na postawione pytania, podam kilka niezbędnych informacji na temat historii ortografii, skupiając się głównie na pisowni wyrazów obcych. Tendencje graficzne i ortograficzne, które upowszechniły się dzięki rozwojowi szesnastowiecznego drukarstwa przyczyniły się do utrzymała polskiej pisowni bez większych zmian do lat 80. XVIII wieku. Początkowo wypracowane zasady nie były jednak przestrzegane przez wszystkich autorów i oficyny drukarskie, w których wydawano dzieła. Upowszechnianiu i ujednolicaniu pisowni towarzyszyła

\footnotetext{
${ }^{1}$ S. J o d ło w s k i, Losy polskiej ortografii, Warszawa 1979, s. 29.

2 Tamże, s. 40.
} 
pewna dowolność i zamieszanie. Temu chaosowi zapobiec miały traktaty ortograficzne (np. Ortografia J. Januszowskiego), popularne wówczas gramatyki łacińskie, pełniące funkcję szkolnych podręczników (np. tzw. Alwar), a także słowniki, np. Słownik Knapiusza, w którym autor zaproponował m.in. pisownię fonetyczną wyrazów polskich oraz - co szczególnie cenne z punktu widzenia czynionych dalej rozważań pisanie wyrazów obcych według ich polskiego brzmienia ${ }^{3}$. Knapski znalazł naśladowców wśród gramatyków XVII i XVIII w., powoływali się oni na jego ortograficzne pomysły, szukając poparcia dla niektórych własnych koncepcji. Jednym z nich był autor Gramatyki dla szkót narodowych O. Kopczyński domagający się wprowadzenia m.in. pisowni fonetycznej zgodnie z zasada:.,, Piszemy, jak mówimy, mówimy, jak piszemy"'. Na rozwój polskiej ortografii mieli wpływ nie tylko poszczególni pisarze, korektorzy, wydawcy czy drukarze, ale także zespoły i instytucje. W 1830 r. Deputacja, wyłoniona spośród członków warszawskiego Towarzystwa Przyjaciół Nauk, kwestionując niektóre ustalenia Kopczyńskiego, wydała Rozprawy i wnioski o ortografii polskiej, w której poza pisownią wyrazów rodzimych zajęto się także pisownią obcych nazw własnych. Deputacja opowiedziała się za dotychczasową pisownią imion obcego pochodzenia na -ya, -ia typu Marya, Julia. Zasadę tę podtrzymali również członkowie Akademii Umiejętności uchwałą z $1891 \mathrm{r}$. Sprzeciwili się jej językoznawcy m.in. A. Brückner, J. Karłowicz i A. Kryński, którzy w Gramatyce języka polskiego z 1897 r. proponowali imiona obcego pochodzenia zapisywać przez $j$ np.: Marja, Julja $a^{5}$. Przez cały wiek XIX wśród pięciu najważniejszych zagadnień ortograficznych znalazł się także problem zapisu $i(y)-j$ po spółgłoskach w wyrazach zapożyczonych ${ }^{6}$. Zajęto się także pisownią nazwisk obcych. W ogłoszonych przez Akademię Umiejętności w 1918 r., a uzupełnionych wyjaśnieniami przez Komisję Językową, tzw. Głównych zasadach pisowni zalecano, aby silnie polszczyć "nazwiska ruskie przez tak zwany przekład ich fonetyczny na język polski, np. Drahomaniw na Dragomanów ${ }^{7}$, Ohonowśkyj na Ogonowski, co zresztą robią i sami Rusini, a zwłaszcza robili to dawniej, podpisując się po polsku"». Do polszczenia nazwisk ukraińskich zachęcała także PAN w Pisowni Polskiej z 1933 r., pisząc, aby: 1/ ukraińskie -śkyj, -śka oddawać przez polskie -ski, -ska i pisać nie Ohonowśkyj, Studyńśka ale Ohonowski, Studyńska, 2/ -wycz oddawać przez -wicz, np. nie Antonewycz, Myronowycz ale Antonewicz, Myronowicz, 3/ -iw oddawać przez -ów, np. Drohomanów, Jacków, bo tylko wówczas możemy odmieniać Drohomanowa, z Jackowem, ,co nie będzie razić ani po polsku ani po ukraińsku”. Również S. Słoński opowiadał się za realizowaniem nazwisk ukraińskich na -śkyj, -ćkyj, -yj na wzór polskich na -ski, -cki, -y, -i, a więc Kotlarewski, Partycki, SmalStocki, Załozny, Myrny, Łepki i odmienianiem ich wg deklinacji przymiotnikowej. Pozostałe zaś nazwiska proponował odmieniać wg deklinacji rzeczownikowej, w tym te na $-y c z$ pisane na wzór polski na -icz, np. Szaszkewicz ${ }^{10}$. Jednak przełomem

${ }^{3}$ Z. Klem e n s i ew i c z, Historia języka polskiego, Warszawa 1999, s. 368.

${ }^{4}$ Tamże, s. 661.

${ }^{5}$ Całą dyskusję na temat ujednolicenia pisowni i protestów przeciwko uchwałom AU przedstawił Jan Łoś. Zob. J . Ło ś, Pisownia polska w przeszłości i obecnie. Zagadnienia i wnioski, Kraków 1917.

${ }^{6}$ Ponadto zajmowano się pisownią: zakończeń bezokolicznika, form imiesłowu uprzedniego, połączeń ke, ge i kie, gie oraz użyciem końcówek -im (-ym), -em oraz -imi, (-ymi), -emi S. Jodłowski, op. cit., s. 53.

${ }^{7}$ Pisownia polska. Przepisy — stowniczek, Polska Akademia Nauk, wyd. X, Kraków 1933, s. 43-44.

${ }^{8} \mathrm{~J}$. Ł o ś, Zasady ortografji polskiej i słownik ortograficzny według Polskiej Akademji Umiejętności, wyd. II, Lwów-Warszawa 1922, s. 31.

${ }^{9}$ Pisownia polska. Przepisy — Stowniczek. Polska Akademia Nauk, Kraków 1933, Wyd. X, s. 43-44.

${ }^{10}$ S. S troń s k i, Pisownia wyrazów stowiańskich w języku polskim, ,Język Polski” 1935, z. 5, s. 108. 
w dziejach polskiej ortografii stało się powołanie w 1935 r. Komitetu Ortograficznego ${ }^{11}$, którego zadaniem była rewizja dotychczasowych zasad ortograficznych i przeprowadzenie reformy pisowni, która miała - jak głosił Komunikat PAU — „pogodzić zdrowy tradycjonalizm z rozumną ewolucją, wynikającą z rozwoju języka i potrzeb życia współczesnego"12 a którego członkowie przedstawiali swoje uwagi na łamach prasy codziennej, gdzie toczyła się zaciekła dyskusja o polskiej ortografii ${ }^{13}$. Zasady transkrypcji nazwisk ukraińskich przedstawione przez Komitet Ortograficzny w niewielkim stopniu różniły się od propozycji wcześniejszych. W Pisowni polskiej z 1936 r., będącej pokłosiem pracy Komitetu, dodano kilka szczegółowych zasad transkrybowania wyrazów pospolitych, i powtórzono, aby nazwiska na -ський, -иький, -ий zapisywać przez -ski, -cki, -i, -y, np. Могильницький - Mohylnycki, Зілинський — Ziłynski, Лепкий — Łepki, Мирний - Myrny i odmieniano przymiotnikowo: Ziłynskiego, Łepkiemu, a nazwiska na -ич zapisywać przez -icz, np. Шашкевич - Szaszkewicz. Zasadnicza zmiana, w stosunku do wcześniej zaproponowanych, polegała na wprowadzeniu zasady, aby nazwiska na -iв pisać przez-iw, nie zmieniać na -ów, ale w dalszych przypadkach, utrzymując postanowienia z 1933 r., przez -ow-, np. Яиків - Jackiw, Jackowa, z Jackowem. Sugerowano, aby polszczyć tylko zakończenia nazwisk, a nie całe nazwiska, czyli nie używać form: Ziłyński, Szaszkiewicz, Lewicki ${ }^{14}$. Przepisy z roku 1936 dotyczące transkrypcji wyrazów ukraińskich zostały uszczegółowione w Uchwale Komitetu Językoznawczego PAN z 20 stycznia 1956 r. Jednak ze względu na ograniczone rozmiary artykułu ograniczę sie do omówienia tylko zasad transkrybowania nazwisk ukraińskich, odwołując się sporadycznie do zasad transkrybowania imion i wyrazów pospolitych. We wstępie do powszechnie wykorzystywanych, a dostosowanych do Uchwał z 1956 r. Zasad pisowni polskiej i interpunkcji S. Jodłowski i W. Taszycki podaja, że w stosunku do zasad pisowni polskiej obowiązującej przez ostatnie 20 lat $\mathrm{w}$ uchwalonej ustawie zmieniono transkrypcje ukraińskich liter $\tau$, $\ddot{i}$. Ponadto wprowadzono rozróżnienie w zapisie zaznaczając, w jaki sposób zaleca się transkrybować nazwiska na -ий, -ський, -иький, -ич, -ів w praktyce bibliotecznej, a w jaki w praktyce wydawniczej, tzn. w praktyce bibliotecznej wszystkie nazwiska należy transkrybować ściśle według podanych przepisów takich samych, jakie dotyczą wyrazów pospolitych. Powtarzając prawie te same nazwiska, proponowano zapis w praktyce bibliotecznej, nр. Мирний — Мугnуj, Могильницький Mohylnyćkyj, Левищький — Łewyćkyj, Зілинський - Ziłynśkyj ${ }^{15}$, Шашкевич -

${ }^{11}$ Komitet Ortograficzny tworzyli członkowie najbardziej kompetentnych instytucji naukowych, kulturalnych i społecznych w kraju, a także przedstawiciele Ministerstwa Wyznań Religijnych i Oświecenia Publicznego. W skład Komitetu wchodziło siedem komisji, w tym komisja grup wyrazowych i wyrazów obcych z Tadeuszem Boyem-Żeleńskim na czele. Posiedzenia komisji, jak i obrady plenarne odbywały się na podstawie referatów. Niektóre z nich ukazały się w na łamach m.in. „Języka Polskiego" i „Poradnika Językowego”. I tak, o odmianie nazwisk francuskich pisał T. Boy-Żeleński (,, Wieczne zmartwienie" (o odmianie nazwisk francuskich), "Wiadomości Literackie" 24 II 1935, nr 588; tenże, W sprawie odmiany nazwisk francuskich, Poradnik Językowy 1935/1936, z. 6), o pisowni imion oraz nazw greckich i łacińskich pisał T. Sinko (Projekt pisowni imion i nazw greckich i łacińskich w języku polskim, Poradnik Językowy 1935/1936, z. 1, 2, 3), z kolei K. Nitsch - o transkrypcji z języka rosyjskiego na język polski ( Nowy projekt (Pol. T-wa dla Badań Europy Wschodniej) transkrypcji z języka rosyjskiego na polski, „Język Polski” XIX, 1934, z. 3, s. 77-83).

${ }^{12}$ Komunikat Komitetu Ortograficznego PAU, ,Język Polski” XX, 1935, s. 46-47.

${ }^{13}$ Z. Kl e m en si e w i c z, Walka o ortografie, [w:] „Język Polski” XX, 1935, z. 2, s. 48-61.

${ }^{14}$ Pisownia polska. Przepisy — słowniczek, wydanie XI, Kraków 1936, s. 53.

15 Transkrypcja nazwiska Зілинський sprawiała wiele kłopotów. W Zasadach pisowni polskiej i interpunkcji S. Jodłowskiego i W. Taszyckiego z 1998 r. jest błędna transkrypcja biblioteczna Zityńskyj, mimo że w wydaniu z 1966 i 1976 r. jest ono poprawna: Ziłynśkyj. Również we wcześniejszych 
Szaszkewycz, Потебня - Potebnia, w praktyce wydawniczej w kontekście polskim po polsku zaś, np. Myrny, Mohylnycki, Łewycki, Ziłynski, Szaszkewicz i odmieniamy po polsku, np. Myrnego, Mohylnyckiego, Łewyckiego, Ziłynskiego. Przytoczono także wcześniejsze ustalenia, że nazwiska na -iв, np. Яикiв pisze się w mianowniku przez -iw, np. Jackiw, a w dalszych przypadkach przez -ow, np. Яикова - Jackowa ${ }^{16}$. Te same zasady powtórzono w Stowniku ortografii języka polskiego pod red. M. Szymczaka ${ }^{17}$, w którym także rozgraniczono zasady transkrybowania ukraińskich nazwisk ze względu na potrzeby biblioteczne i wydawnicze. Podano odmianę tych samych nazwisk, uzupełniając jedynie odmianę nazwiska Jackiw o formy liczby mnogiej: Jackowowie, u Jackowów, z Jackowami. Nie wszystkie współczesne słowniki ortograficzne podają, jak należy transkrybować lub transliterować nazwiska ukraińskie ${ }^{18}$. Te, w których zawarte są takie informacje, proponują, aby zasady transliteracji oparte były na Polskiej Normie PN-83, N-01201, obowiązującej od 1 lipca 1984 r. $^{19}$ albo Polskiej Normie PN-ISO 9 obowiazzującej od 1 lutego 2000 roku: Transliteracja znaków cyrylickich na znaki tacińskie. Języki stowiańskie $i$ niestowiańskie ${ }^{20}$, z kolei zasady transkrypcji mają być zgodne z uchwałami Komitetu z 1956 r. Jedyną nowością w Wielkim stowniku ortograficznym PWN jest wzmianka, że w przypadku nazwisk historycznych lub znanych w wersji polskiej można zastosować wersję polską również w transkrypcji, np. Wiszniowiecki, Chmielnicki, Rudnicki,Ziłyński ${ }^{21}$.

Omawiając zasady transkrypcji podane w słownikach ortograficznych PWN z 2000, 2003 oraz 2013 r., jednoznacznie należy stwierdzić, że są takie same, gdyż opierają się na ustawie z $1956 \mathrm{roku}^{22}$. Zupełnie inaczej jest z zasadami transliteracji. W przywołanych słownikach z 2003 i 2013 r. reguły zapisu dziesięciu liter: $\tau, \epsilon$, $\mathscr{H}, i, i, u, u, ю$ oraz $я$ uległy zmianie, ponieważ zmieniły się zasady translitaracji (o tym pisałam powyżej). Nie będę jednak przedstawiać tych zmian ze względu na znikomą liczbę transliterowanych nazwisk w omawianym materiale źródłowym, jaki stanowią dwa dzienniki ogólnopolskie: „Gazeta Wyborcza” (dalej jako GW) oraz „Rzeczpospolita” (dalej jako Rz) z 1991 i 2012 roku $^{23}$.

wszystkich wydaniach Wielkiego słownika ortograficznego PWN pod red. E. Polańskiego w nazwisku tym pojawiła się rosyjska litera bl zamiast ukraińskiej $u$ : Зільлнький. Błąd ten usunięto dopiero w wydaniu z $2013 \mathrm{r}$.

16 S. Jodłowski, W. Taszycki, Zasady pisowni polskiej i interpunkcji ze słownikiem ortograficznym, Wrocław 1966, wyd. XV, s. 93-94. Por. tychże, Zasady pisowni polskiej i interpunkcji. Słownik ortograficzny, Wrocław 1998, wyd. XXII, s. 114-115.

${ }^{17}$ Słownikortografiijęzyka polskiego wraz z zasadamipisowni interpunkcji, pod red. M. Szy mczaka, Warszawa 1986, PWN, s. 144-155.

18 Zob. m.in. A. Jas in ow s ka-Czarny, Słownik ortograficzny języka polskiego, Wrocław 2000; Wielki słownik ortograficzno-fleksyjny, pod red. J. P odrackiego, Warszawa 2001.

${ }^{19}$ Wielki słownik ortograficzny PWN z zasadami pisowni i interpunkcji, pod red. E. Polańskiego, Warszawa 2003, s. 108 (dalej jako WSO). Por. Nowy słownik ortograficzny PWN, pod red. E. P ol ań s ki e g o, Warszawa 1996, 2000, 2013.

20 Źródło elektroniczne, [w:] http://so.pwn.pl/zasady.php?id=629694 (25.10.2013).

${ }^{21}$ Wielki słownik ortograficzny PWN z zasadami pisowni i interpunkcji, pod red. E. Polańskiego, Warszawa 2003, s. 113.

22 Obecnie Rada Języka Polskiego jest instytucją władną w sprawie ustalania norm, w tym przepisów ortograficznych. Na pytanie Stowarzyszenia Warszawa-Kijów skierowane do RJP w 2001 r. o pisownię nazw ukraińskich w polskiej wersji odpowiedziano, że wszelkie wątpliwości związane z zasadami zapisu wyrazów w różnych alfabetach rozwiewa "Nowy słownik ortograficzny PWN" pod red. E. Polańskiego. Zob. źródło elektroniczne, [w:] http://www.rjp.pan.pl/index.php?option=com_cont ent\&task=view\&id=230\&Itemid=1 (07.10.2013).

${ }^{23}$ Roczniki te zostały wybrane nieprzypadkowo. W 1991 roku Ukraina uzyskała niepodległość, dzięki czemu polskie media zaczęły ją traktować jako samodzielny byt polityczny, a nie część ZSRR. Z kolei 2012 był ostatnim rokiem, kiedy obydwie gazety ukazywały się przez całe dwanaście miesięcy. 
Analizę rozpocznę od omówienia sposobów polszczenia zakończeń ukraińskich nazwisk. Następnie wskażę niepoprawne realizacje przyrostków i błędne transkrypcje występujące w rdzeniu nazwiska. Przykłady ilustrujące omawiane problemy ograniczę do niezbędnego minimum.

1. Zgodnie $\mathrm{z}$ zasadami polszczenia nazw własnych ukraińskie nazwiska zakończone na -ський, -цький mogą otrzymać w mianowniku liczby pojedynczej polskie zakończenia -ski, -cki, np. Lubacziwski ${ }^{24}$, Kocyłowski, Choroszkowski, Dyminski, Kolomojski. Nazwiska postaci historycznych są polszczone, np. Hruszewski, Szeptycki. Tylko w materiale źródłowym z 1991 r. można znaleźć różne zapisy zakończeń, np. -śkyj: Lubacziwśkyj, Jaworiwśkyj, w których zastosowano transkrypcję biblioteczna, albo -skij: Juchnowskij, Ingulskij, będące wynikiem ruszczenia nazwisk ukraińskich ${ }^{25}$ lub -sky: Gorochowsky, gdzie literę $u$ zrealizowano jak $y^{26}$. W tekstach z 1991 r. (nawet w tym samym numerze, w obu dziennikach) mogły pojawić się te same nazwiska raz przetranskrybowane, a innym razem przetransliterowane. W tekstach z 2012 r. takich przykładów nie odnotowałam, a transliteracja nazwisk ukraińskich należy do rzadkości i dotyczy nazwisk osób mało znanych.

W całym materiale nazwiska na $-s k i,-c k i$ sa prawidłowo odmieniane. Wyjątek stanowi jedna błędna realizacja: $\mathrm{w}$ narzędniku zamiast końcówki -'im jest -ym: Myrosławem Lubaczywskym (GW, 3 VI 1991), wynikająca z użycia w tym tekście niepoprawnej formy mianownikowej: Lubaczywsky.

2. W praktyce wydawniczej ukraińskie nazwiska zakończone na -uй mogą otrzymać -y, np. Мирний - Myrny i odmieniamy je jak nazwiska polskie odprzymiotnikowe, $\mathrm{z}$ kolei $\mathrm{w}$ praktyce bibliotecznej nazwiska mają postać $-y j$, np. Myrnyj.

Wynotowałam niewiele nazwisk odprzymiotnikowych: Zakureny utworzone od imiesłowu przymiotnikowego закурений oraz nazwisko Chwylowy, a także poprawną formę dopełniacza „,... miało dostęp do wierszy Aleksandra Tichego" (GW, 13 IX 1991), „Zdaniem ... Serhija Sołodkiego” (Rz. 20 XII 2012). Przeważają jednak realizacje mianownikowe na $-y j$, np. Slipyj, Sołodkyj, które stosuje się w praktyce bibliotecznej. Pojawiają się one zarówno w tekstach z 1991 r., jak i tych z 2012. W przypadkach zależnych nazwiska odprzymiotnikowe sązrealizowane niepoprawnie: „„... jeszcze za życia kardynała Slipyja” (GW, 20-21 IV 1991), „... z Jozefem Slipyjem” (Rz, 3 IV 1991). Wynika to z niestosowania przymiotnikowej odmiany wymienionych nazwisk. Najprawdopodobniej nie polszcząc tych nazwisk, chciano zachować ich ukraińskie brzmienie i wyrównać temat do formy mianownika, aby łatwiej było go utworzyć.

3. Zgodnie z obowiązującymi zasadami polszczenia nazwisk ukraińskich przyrostek $-\iota \iota \mathrm{w}$ transkrypcji wydawniczej powinien być pisany jak -icz, a jedynie w transkrypcji bibliotecznej jak $-y c z$.

$\mathrm{Z}$ materiału źródłowego wypisałam tylko trzy nazwisko ukraińskie zakończone na -icz: Ławrynowicz, Sembratowicz, Jakubowicz, przy których kontekst wskazuje, że odnoszą się do obywateli Ukrainy. Być może jest to transliteracja tych nazwisk, a $\mathrm{w}$ rdzeniu tego pierwszego nazwiska pojawiła się niepoprawna realizacja $y$ zamiast $i$. Pozostałe nazwiska podane $\mathrm{w}$ dziennikach $\mathrm{z}$ zakończeniem na -icz dotyczą

${ }^{24}$ Ze względu na dużą powtarzalność tych samych nazwisk w materiale prasowym pomijam w tekście głównym pełny opisu bibliograficzny. Zamieszczam go tylko wówczas, gdy omawiam szczegółowo błędne realizacje w zapisie nazwiska i podany przykład jest jednostkowy.

${ }^{25} \mathrm{~W}$ praktyce bibliotecznej nazwiska rosyjskie zakończone na -ский, -цкий, transkrybuje się jako -skij, -ckij.

${ }^{26}$ Zgodnie z zasadami transkrypcji wyrazów ukraińskich literę $u$ oddajemy przez $y$. Zob. WSO, s. 112. 
obywateli Białorusi albo Rosji. Najprawdopodobniej chcąc jednoznacznie wskazać na nazwiska ukraińskie, dziennkarze bardzo konsekwentnie zastosowali takie rozróżnienie w całym materiale. Nazwisk z przyrostkiem -ycz jest bardzo dużo, dlatego ograniczę się do kilka: Szuchewycz, Popowycz, Janukowycz, Daszkewycz. Odmiana nazwisk na -ycz nie nastręcza problemów, np. Rozmowa z ... Popowyczem (GW, 13 I 2012), "Dynastia Janukowyczów” (Rz. 11 IX 2012).

4. Bez wskazania czy jest to transkrypcja biblioteczna, czy też wydawnicza nazwiska z przyrostkiem -is w mianowniku mają mieć postać -iw, np. Яuкiв - Jackiw, a w przypadkach zależnych -ow-, np. Jackowa, Jackowowi itp.

Odnotowałam niewiele nazwisk na -iw: Kaśkiw, Petriw, Pawliw oraz: „... ostrożnie podchodzą do publikacji Pawliwa" (Rz. 13 II 2012). Trudno na podstawie tego jednego przykładu wyciagać daleko idące wnioski o niestosowaniu w pozostałych przypadkach postaci -ow-. Być może nie użyto jej, aby łatwiej było podać formę podstawową nazwiska ${ }^{27}$. Ponadto uniknięto $\mathrm{w}$ ten sposób podania identycznej postaci nazwiska także z dzierżawczym formantem -ow, np. Каськов. Przypuszczam, że to czego obawiali się autorzy Pisowni polskiej z 1933 r., aby nie używać formy Jackiwa, bo to raziłoby po polsku i po ukraińsku, dla współczesnego Polaka jest formą bardziej przejrzysta, mimo że niezgodną z obowiązującymi zasadami polszczenia nazwisk ukraińskich.

5. Wydaje się, że poza nazwiskami ukraińskimi na -ський, -иький, -ий, -ів, -ич, które mogą otrzymać polskie zakończenia, ważkim problemem do rozwiązania pozostaje realizacja takich nazwisk ukraińskich, które do tej pory nie doczekały się systemowych rozwiązań. Do grupy tej zaliczyłabym nazwiska typu: Сокіл Sokit, Козел - Kozet, Чорновіл - Czоrnowit, Білопіл - Biłopił, których odmiana budzi wątpliwości ${ }^{28}$ oraz nazwiska z przyrostkami na $-u b,-H b$, które to zgodnie z ogólną zasadą transkrypcji wyrazów ukraińskich powinny być oddawane za pomocą polskiego -eć, -eń tak jak, np. nazwiska równe imionom: Уманець -Umané́, Грицько - Hryćko, Ромась - Romaś lub apelatywy, nр. швеиь — szweć, день — deń29. W badanym materiale znalazły się m.in. takie nazwiska: Kałyneć, Wołyneć, Horyń oraz Jemec. Ta ostatnia niepoprawna realizacja najprawdopodobniej spowodowana jest spolszczeniem formantu na -ec. Przykłady takich dwojakich realizacji tego formantu można znaleźć też wśród nazwisk postaci historycznych, np. Boroweć ale Konowalec. Pociaga to za sobą dalsze konsekwencje w odmianie: Borowcia ale Konowalca, Borowciowi ale Konowalcowi itd. W analizowanym materiale znalazł

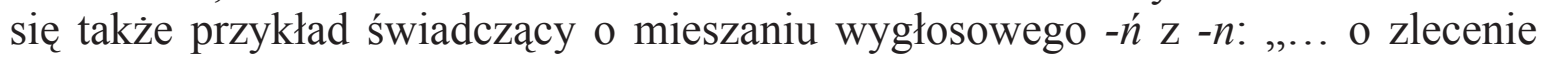
zabójstwa ... Jewhena Szczerbania ...” (Rz. 12-13 V 2012). W formie podstawowej nazwisko brzmi Szczerban, a nie jak wynikałoby z odmiany Szczerbań.

$\mathrm{Na}$ zakończenie chciałabym podzielić się kilkoma uwagami. Z analizy dwóch gazet ogólnopolskich wynika, że dziennikarze częściej stosowali transkrypcję niż transliterację nazwisk ukraińskich. Polszczyli przede wszystkim ukraińskie nazwiska na -ski, -cki, zapisując je zgodnie z tradycją wydawnicza. Z $\mathrm{Z}$ kolei nazwiska na $-y c z,-y j$ transkrybowali zgodnie z praktyką biblioteczną. Ponadto w przypadkach zależnych używali niepoprawnych form typu Slipyja, Pawliwa zamiast zgodnych z zasadami polszczenia nazwisk ukraińskich form Slipego, Pawłowa. Wydaje się, że należy zweryfikować zasady transkrypcji nazwisk ukraińskich, aby nie dochodziło

27 Przypuszczenia swoje opieram na analizie nazwisk ukraińskich, w których powinno dojść do takiej samej wymiany samogłoskowej i : o, np. przy odmianie nazwiska męskiego Czornowit.

${ }^{28} \mathrm{~W}$ obydwu dziennikach do formy podstawowej dodawano końcówki fleksyjne, np. ,...zastępcy Czarnowiła” (GW, 22 IV 1991), „Przewaga ... nad Wiaczesławem Czornowiłem zmalała” (GW, 2 XII 1991).

${ }^{29}$ Por. S. Słoński, op. cit. s. 108; S. Jodłowski, W. Taszycki, op. cit. s. 93. 
na przykład w tym samym tekście do stosowania transkrypcji wydawniczej i bibliotecznej, co jest praktyką nagminnie stosowaną. Uzasadnione jest również uporządkowanie przepisów i uczynienie je bardziej konsekwentnymi, opracowanie bardziej szczegółowych wytycznych dotyczące transkrypcji wyrazów ukraińskich, w tym także antroponimów ${ }^{30}$, ze szczególnym zwróceniem uwagi na transkrypcję wewnątrz wyrazu, aby uniknąć polszczenia i/lub ruszczenia wyrazów. Dotyczy to m.in. transkrypcji: litery $\pi\left(*\right.$ Salenko, ${ }^{*}$ Kowalenko, $*$ Wasylenko, ${ }^{*}$ Lewczenko ${ }^{31}$, litery $u$ (*Lisicki, *Kunicki, *Dworniczenko, *Tichyj, *Trofimiak, *Winniczenko), liter: $m b, \partial b, н b\left({ }^{*}\right.$ Sitko, *Hetmanczuk, *Fiedko, *Linko), litery ${ }^{*}$ (*Pełeński, *Pohrebyński, * Łopatyński), litery $\mu$ (*Fomienko). Warto bowiem poświęcić więcej uwagi transkrypcji i transliteracji wyrazów ukraińskich w języku polskim ze względu na jeszcze jeden powód - coraz ściślejszą współpracę między Polską a Ukrainą na różnych poziomach i w wielu dziedzinach. Pewna dowolność w transkrybowaniu nazwisk ukraińskich prowadzi do zakłócenia komunikacji między nadawcą a odbiorca, zwłaszcza, jeżeli w bardzo krótkim czasie (czasami w odstępie jednodniowym) można zobaczyć w gazetach różne realizacje tego samego nazwiska, np. Lewko Łukjanenko, Lewko Łukjanienko, Łewko Łukianenko, Lewko Łukianienko, podane niejednokrotnie wraz z różnymi realizacjami imienia. Prasa stanowi jedno ze źródeł informacji, lecz podobne problemy z transkrypcją i transliteracją występują m.in. w pracach popularnonaukowych czy w Internecie ${ }^{32}$.

${ }^{30}$ Wydaje się, że pierwszy krok $\mathrm{w}$ tym kierunku został uczyniony. Zob. T. Мельничук, Антропоніми в українсько-польській міжмовній комунікаиії, Ужгород 2013.

${ }^{31}$ Znakiem * zaznaczam niepoprawne realizacje wypisane z materiału źródłowego.

${ }^{32}$ Oto jeden z bardziej wymownych przykładów: nazwisko i imię obecnego prezydenta Ukrainy przetransliterowane jest jako Viktor Fedorovič Anukovič, przetranskrybowane zaś: Wiktor Fedorowycz Janukowycz (transkrypcja), Wiktor Fedorowicz Janukowicz (transkrypcja spolszczona), Viktor Fedorovych Yanukowych (transkrypcja oficjalna). 